\title{
EFFECTS OF SUNNY AND SHADY ASPECTS ON PASTURE YIELD, DIGESTIBILITY AND SHEEP PERFORMANCE IN CANTERBURY
}

\author{
J. E. Radcliffe, S. R. Young \\ Ministry of Agriculture and Fisheries, Lincoln College \\ D. G. Clarke \\ Biochemistry Department, Lincoln College, Canterbury
}

\begin{abstract}
Annual pasture dry matter (DM) production from improved browntop-dominant hill pastures varied from 3.5 to $7.4 \mathrm{t} \mathrm{DM} / \mathrm{ha}$ over three years. A south aspect produced on average 14\% more dry matter than a north aspect; both had spring and autumn growth peaks, and a summer depression which was greater on the north aspect.

A nucleus flock of hoggets was set-stocked on each aspect from October to June. and numbers of extra sheep were adjusted monthly if necessary to maintain similar quantities of available herbage on each aspect. Both nucleus flocks generally grew at similar rates so their seasonal growth patterns were similar. In the second and third year those on the south aspect grew 3 to 5\% more wool. Net liveweight gain per hectare was greater on the south than the north aspect in the first year owing to a higher seasonal stocking rate on the south aspect, but in two subsequent years production was similar.

The digestibility of pasture on offer to stock was 75 to $80 \%$ in spring and 45 to $50 \%$ in summer. It recovered to 50 to $55 \%$ in autumn then deteriorated to 40 to $45 \%$ in June. Small differences were measured between aspects.
\end{abstract}

\section{INTRODUCTION}

THERE are few reports on the effect of aspect on pasture productivity in New Zealand and even less information on stock performance. In the North Island, Gillingham (1973), Radcliffe (1971), and Suckling (1975) found higher dry matter (DM) yields from north-facing or sunny slopes than from south-facing or shady slopes: but in the South Island some measurements have shown the reverse (White et al., 1972; Radcliffe, 1971).

Many soil, climate and pasture factors affect productivity, but on hillsides, variations in soil depth and development, microclimate, the grazing pattern of stock and consequent transference of fertility, add to the complexity of estimating production. 
It is a common observation that stock graze sunny country in preference to colder, damper slopes and some farmers consider that stock grow better on sunny country. How-ever, no comparisons of stock growth have been recorded.

The nutritive quality of pasture which grows on sunny and shady country is also a matter of opinion, and in general the danthonias, browntop and sweet vernal, common on drier slopes, are held in poor regard. Coop et al. (1953) reported very low levels of calcium, phosphorus, and protein in hill and high country South Island pastures containing these grasses, especially in summer and winter.

In 1973 an examination of some of these factors was begun on improved hill pastures in North Canterbury. The purpose was to measure pasture growth, to find when it grew, how much it grew, which species contributed, and how digestible was the pasture on offer to stock throughout the season. The performance of young stock was also measured when they were confined to a sunny or shady face, under a set-stocking regime. Set-stocking over extensive hill blocks is common in the district. Some data from three years of measurements are given here.

\section{EXPERIMENTAL}

The study area at Coopers Creek (43" 15 ' S, 172" OS' E) is on a Hurunui hill soil —a yellow-brown earth which covers 344 000 ha of foothills from Marlborough to North Otago. Slopes lie at 20 to $30^{\circ}$ between 290 and $440 \mathrm{~m}$. A north to north-west facing or sunny aspect (12.7 ha) and a south-west facing or shady aspect (3.7 ha) were separately fenced and continuously grazed with Romney ewe hoggets from spring to autumn.

\section{Climate}

Annual rainfall has averaged $1430 \mathrm{~mm}$ and two weeks without rain is rare. Daily mean air temperatures $(3 \mathrm{~cm}$ above ground) were about 16" $\mathrm{C}$ in January and 4" $\mathrm{C}$ in July. Soil temperatures (Table 1 ) on the sunny face were 3 to $8^{\circ} \mathrm{C}$ higher than those on the shady face. The site is exposed to strong NE and NW winds, often $70 \mathrm{~km} / \mathrm{h}$ or more and with a daily windrun often exceeding $600 \mathrm{~km}$ and sometimes $2500 \mathrm{~km}$. These winds have undoubtedly reduced the effectiveness of the seasonal rainfall (Table 2). Soil moisture levels were up to $30 \%$ lower on the sunny compared with the shady aspect at all times of the year and they sometimes reached wilting point between December and March. 
TABLE 1: MEAN DAILY SOIL TEMPERATURES $\left({ }^{\circ} \mathrm{C}\right)$ AT $10 \mathrm{~cm}$ DEPTH ON SUNNY AND SHADY ASPECTS FOR TWO SEASONS

\begin{tabular}{|c|c|c|c|c|c|c|c|c|c|c|c|}
\hline \multirow[b]{2}{*}{ Year } & \multirow[b]{2}{*}{ A spect } & \multicolumn{3}{|c|}{ Spring } & \multicolumn{3}{|c|}{ Summer } & \multicolumn{3}{|c|}{ A utumn } & \multirow[b]{2}{*}{ Jun. } \\
\hline & & Sep. & Oct. & $\overline{N o v}$. & $\mathrm{Dec}$. & Jan. & Feb. & Mar. & Apr. & May & \\
\hline \multirow[t]{2}{*}{$1974-5$} & Sunny & 10.8 & 12.3 & 17.2 & 20.1 & 20.9 & 20.3 & 17.7 & 16.2 & 12.2 & 8.0 \\
\hline & Shady & - & - & - & 17.4 & 18.0 & 16.1 & 13.9 & 10.1 & 6.4 & 1.8 \\
\hline \multirow[t]{2}{*}{ 1975-6 } & Sunny & 11.8 & 13.7 & 15.5 & 17.9 & 19.4 & 17.4 & 18.5 & 17.0 & 12.1 & 7.9 \\
\hline & Shady & 5.2 & 8.0 & 9.4 & 12.4 & 14.0 & 12.1 & 11.3 & 9.4 & 5.8 & 1.9 \\
\hline
\end{tabular}


IUNNY AND SHADY ASPECTS

TABLE 2: SEASONAL AND ANNUAL RAINFALL (mm) MEAN FOR SUNNY AND SHADY ASPECTS

\begin{tabular}{|c|c|c|c|c|c|}
\hline Year & Spring* & Summer & Autumn & Winter & Annual \\
\hline $1973-4$ & 250 & 310 & 520 & 260 & 1340 \\
\hline 1974-5 & 450 & 400 & 540 & 310 & 1700 \\
\hline $1975-\mathrm{G}$ & 380 & 340 & 250 & 290 & 1260 \\
\hline
\end{tabular}

*Sep. Oct. Nov.

\section{SOILS}

The Hurunui hill soils are very stony with a depth from $<0.4 \mathrm{~m}$ to $>1 \mathrm{~m}$. Topsoils to $10 \mathrm{~cm}$ are moderately acid $(\mathrm{pH}$ 5.2 to 5.5 ) with moderately low phosphate and potassium levels. Soils are more weathered on the sunny than the shady aspect (P. J. Tonkin, pers. comm.) and the shady soil has a higher $\mathrm{pH}$, and available $\mathrm{P}, \mathrm{K}$ values and also more total $\mathrm{C}$ and $\mathrm{N}$.

\section{PASTURES}

These have been developed from silver and fescue tussock grasslands formerly in beech forest. Browntop and sweet vernal are abundant with some crested dogstail, Yorkshire fog, Poa pratensis, perennial ryegrass, and, on the sunny aspect, danthonia and Agropyron scabrum. White clover is the main legume with some suckling and striated clover on the sunny aspect. Flatweeds and moss are abundant. The pastures have been annually topdressed with superphosphate (100 to $200 \mathrm{~kg} / \mathrm{ha}$ ) for 25 years and sometimes extra sulphur and molybdenum.

Pasture production was measured monthly by the trim technique (Radcliffe, 1971) from random sampling positions within soil mapping units (90 samples in Year 1, 64 in Years 2 and 3). Sampling areas $\left(0.25 \mathrm{~m}^{2}\right)$ protected by cages $\left(1 \mathrm{~m}^{2}\right.$ basal area) were clipped with hand shears to about $1 \mathrm{~cm}$ above ground level. Available dry matter (ADM) was assessed every two weeks by similarly clipping an unprotected $0.1 \mathrm{~m}^{2}$ area near each sampling position used for pasture production measurements. Herbage from these cuts was bulked according to soil units and analysed for botanical composition and percentage digestibility (Tilley and Terry, 1963).

SHEEP

In September newly shorn hoggets were randomly allocated to the sunny or shady aspect where they remained until June, apart 


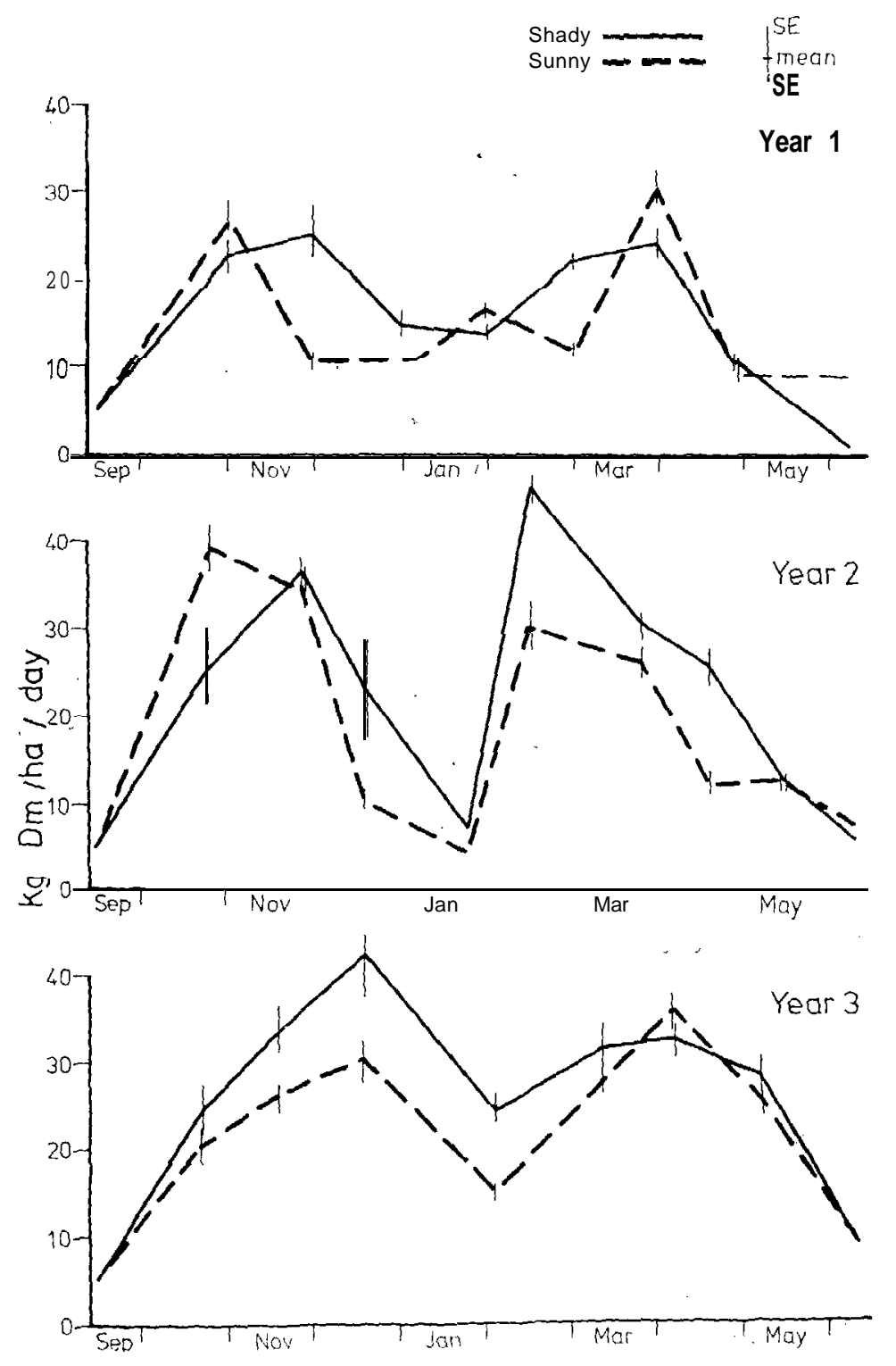

FIG. 1: Seasonal pattern of pasture growth on sunny and shady aspects for three years. 
from a week or two away from the study area in late March for shearing. The stocking rate for each aspect was determined monthly according to the available feed position (ADM pasture measurements, made a day or two earlier). Sheep numbers were adjusted in an attempt to maintain similar levels of available pasture on each aspect. A nucteus flock remained on each aspect through the season and additional sheep were put on or off as necessary. ,411 sheep were weighed monthly and drenched every one or two months. In the first year the initial stocking rate was determined from pasture production measurements taken in the preceding two years from a restricted number of sampling positions. These showed that the shady aspect had grown up to $70 \%$ more pasture than the sunny aspect.

\section{RESULTS}

\section{PASTURE PRODUCTION,}

Spring growth generally began about mid-September, although in the third year it was delayed by late snowfalls on surrounding hills. Average daily growth rates as calculated from measured growth between cuts generally showed spring and autumn peaks with a summer trough although the shady aspect produced more dry matter in February (Fig. 1). Annual yields and the contribution of grasses, legumes, dead plant material, and weeds are given in Table 3. Dead material accumulated particularly in late summer and autumn and tufts of browntop and flower stalks of grasses often blew around the hillsides, accumulating in drifts around obstacles. Legumes on the sunny aspect, made up of white clover and some suckling and striated clover, grew mostly in spring, but on the shady aspect, where annual legumes were less abundant, most white clover grew in early summer. There was little legume growth in autumn on either aspect.

\section{AVAILABLE Dry MatTer (ADM)}

At most times, similar amounts of ADM (measured about $1 \mathbf{~ c m}$ above ground level) were recorded on each aspect. In the first year, ADM was generally below $500 \mathrm{~kg} \mathrm{DM} / \mathrm{ha}$ but rose to 1000 to $1500 \mathrm{~kg} \mathrm{DM} / \mathrm{ha}$ in spring. In subsequent years it was usually between 500 and $1000 \mathrm{~kg} \mathrm{DM} / \mathrm{ha}$ but rose to $1500 \mathrm{~kg}$ $\mathrm{DM} /$ ha on the sunny aspect in the second summer.

Grazing pressures, defined as ADM/stocking rate and digestible $\mathrm{ADM} /$ stocking rate, inevitably varied between measurement da\&s, because they depended not only on growth but on the time inter- 
72

PROCEEDINGS N.Z. GRASSLAND ASSOCIATION

TABLE 3: PASTURE PRODUCTION (t DM/ha) AND COMPOSITION

\begin{tabular}{|c|c|c|c|c|c|}
\hline & & & sunny & Shady & $\begin{array}{c}\text { Sig. of } \\
\text { Difference }\end{array}$ \\
\hline $\begin{array}{l}\text { 1973-4: } \\
\text { Yield } \\
\text { SE }\end{array}$ & ::": & :':! & $\begin{array}{l}3.50 \\
0.13\end{array}$ & $\begin{array}{l}3.73 \\
0.17\end{array}$ & ns \\
\hline $\begin{array}{llllll}\text { 1974-5: } & & & & \\
\text { Yield } & & & & & \\
\text { SE } & & & \ldots & \\
& & . & \ldots & \ldots .\end{array}$ & $\begin{array}{l}\cdots \\
.\end{array}$ & ."' & $\begin{array}{l}5.51 \\
0.23\end{array}$ & $\begin{array}{l}6.29 \\
0.29\end{array}$ & $(*)$ \\
\hline 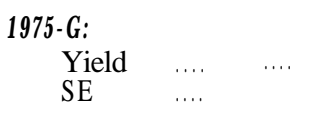 & $\begin{array}{l}\cdots \\
\cdots\end{array}$ & $\ldots$ & $\begin{array}{l}6.06 \\
0.23\end{array}$ & $\begin{array}{l}1.37 \\
0.42\end{array}$ & $*$ \\
\hline $\begin{array}{l}\text { Mean yield } \\
\text { SE } \quad \ldots\end{array}$ & $\cdots$ & $\ldots$ & $\begin{array}{l}\mathbf{5 . 0 2} \\
0.12\end{array}$ & $\begin{array}{l}\mathbf{5 . 8 0} \\
0.18\end{array}$ & $*$ \\
\hline $\begin{array}{l}\text { \% Composition (by dry } \\
\text { Grasses .... } \\
\text { Legu nes } \\
\text { Dead matter .... } \\
\text { Weeds ... }\end{array}$ & $\begin{array}{c}\text { weig } \\
\ldots \\
\ldots \\
\ldots\end{array}$ & $\begin{array}{l}\text { it) } \\
\cdots \\
\cdots \\
\cdots\end{array}$ & $\begin{array}{r}57 \\
14 \\
? 4 \\
5\end{array}$ & $\begin{array}{r}63 \\
11 \\
21 \\
5\end{array}$ & \\
\hline
\end{tabular}

$(*)$ nearly significant at $5 \%$.

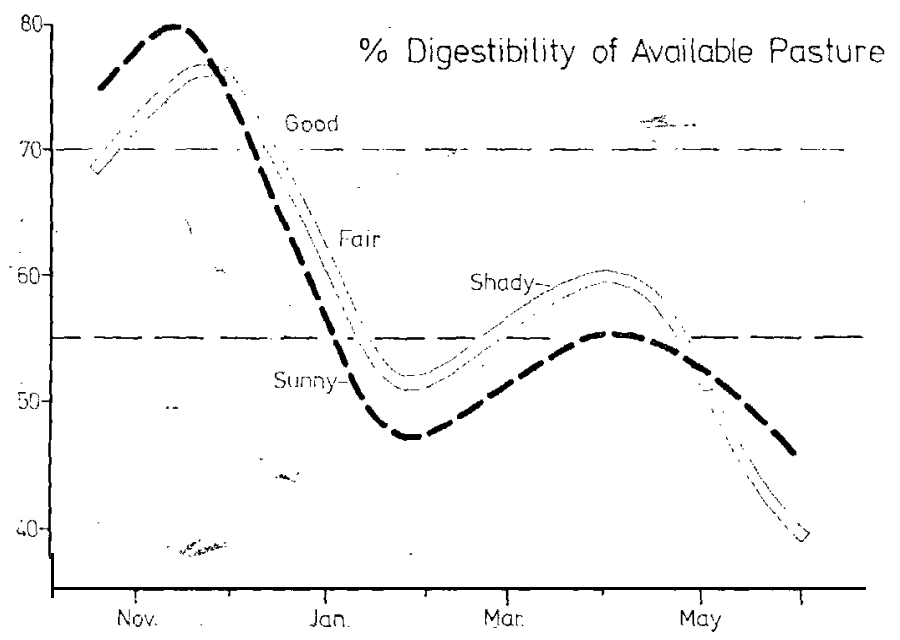

Fic. 2: Seasonal pattern of \% digestibility in available pasture dry maffer on sunny and shady aspects. Mean over three years. 
vals between stocking rate adjustments, and the date of ADM measurement. However, within these constraints, grazing pressures were generally similar between aspects at most measurement dates, except in the first year when grazing pressures were higher on the shady face. They were also comparable from year to year apart from the shady aspect in the first year as mentioned above.

\section{DIGESTIBILITY}

On the sunny aspect the pasture reached maximum digestibilities of around $80 \%$ in November (Fig. 2) falling to 45 to $50 \%$ in January of each year. Then the digestibilities improved until late April but this improvement never lasted more than three weeks, and digestibilities never exceeded $65 \%$ (data not shown).

On the shady aspect the digestibility of ADM in October was up to $10 \%$ lower than that on the sunny aspect and it reached a peak around $75 \%$ in late November. Thereafter, it tended to be about $5 \%$ higher than that on the sunny aspect until late autumn when it dropped to $40 \%$ and lower in early June.

\section{SheEP PRODUCTION}

Hoggets maintained on each aspect generally grew at similar rates (Fig. 3) although there were short-lived differences often associated with stocking rate adjustments. However, liveweight gains were not clearly related to grazing pressure on either aspect. The seasonal growth pattern was similar in each year.

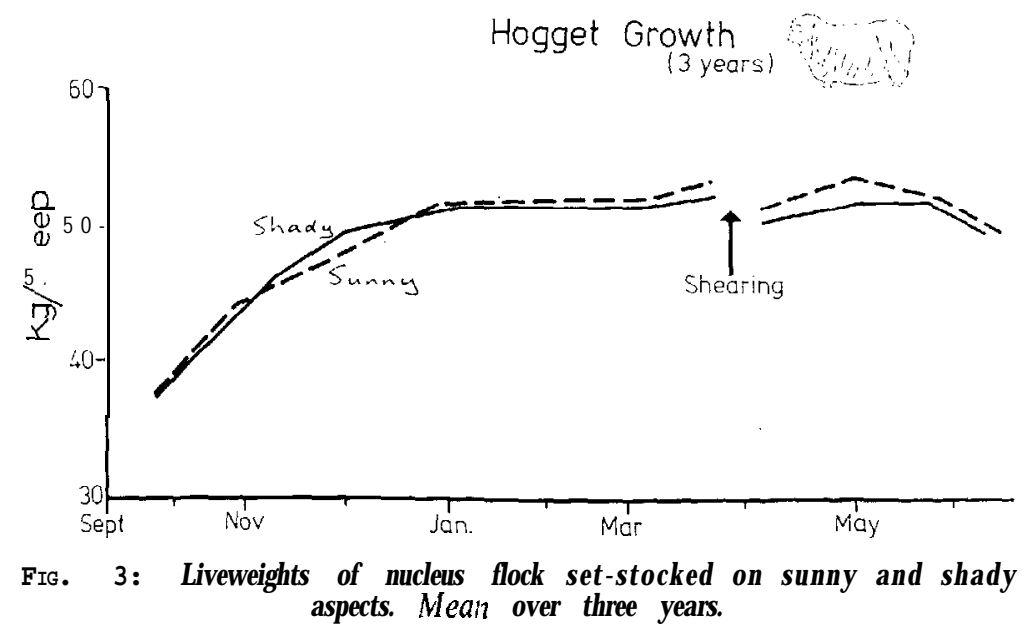


TABLE 4: SHEEP PRODUCTION ON SUNNY AND SHADY ASPECTS FOR THREE YEARS

\begin{tabular}{|c|c|c|c|c|}
\hline & Aspect & $\begin{array}{c}19734 \\
(19 \text { Sep.-5 Jun) }\end{array}$ & $\begin{array}{c}1974-5 \\
(14 \text { Oct }-29 \text { May) }\end{array}$ & $\begin{array}{c}19756 \\
(9 \text { Oct }-10 \text { Jun. })\end{array}$ \\
\hline Liveweight at start (kg/sheep of ñucleus flock)- & $\begin{array}{l}\text { Sunny } \\
\text { Shady }\end{array}$ & $\begin{array}{l}31.4 \\
31.2\end{array}$ & $\begin{array}{l}39.6 \\
40.2\end{array}$ & 37.9 \\
\hline $\begin{array}{l}\text { Mean seasonal stocking rate (S/R) in numbers/ha } \\
\text { (Range in monthly } S / R \text { ) }\end{array}$ & $\begin{array}{l}\text { SE } \\
\text { Sunny } \\
\text { Shady }\end{array}$ & $\begin{array}{c}2.73 \mathrm{~ns} \\
6.9 \\
(5.3-10.1) \\
12.8 \\
(7.5-16.7)\end{array}$ & $\begin{array}{c}3.42 \mathrm{~ns} \\
13.4 \\
(7.1-18.5) \\
12.8 \\
(10.0-14.8)\end{array}$ & $\begin{array}{c}3.01 \mathrm{~ns} \\
13.2 \\
(11.8-16.5) \\
11.7 \\
(10.0-12.4)\end{array}$ \\
\hline $\begin{array}{l}\text { Net liveweight gain over season as } \mathrm{kg} / \mathrm{sheep} \text { of } \\
\text { nucleus flock }\end{array}$ & $\begin{array}{l}\text { Sunny } \\
\text { Shady } \\
\text { SE }\end{array}$ & $\begin{array}{l}22.2 \\
17.3 \\
2.76 * *\end{array}$ & $\begin{array}{l}13.0 \\
13.8 \\
2.5] \mathrm{ns}\end{array}$ & $\begin{array}{l}9.7 \\
11.7 \\
2.55^{* *}\end{array}$ \\
\hline $\begin{array}{l}\text { Net liveweight gain over season as } \mathrm{kg} / \mathrm{ha} \text { (seasonal } \\
\mathrm{S} / \mathrm{R} \times \text { net gain of nucleus flock) }\end{array}$ & $\begin{array}{l}\text { Sunny } \\
\text { Shady }\end{array}$ & $\begin{array}{l}133 \\
220\end{array}$ & $\begin{array}{l}173 \\
173\end{array}$ & $\begin{array}{l}128 \\
137\end{array}$ \\
\hline Mean $S / R$ until shearing in numbers/ha & $\begin{array}{l}\text { Sunny } \\
\text { Shady }\end{array}$ & 12.9 & 13.0 & $12: 8$ \\
\hline $\begin{array}{l}\text { Fleece growth in } 6 \text { months as } \mathrm{kg} / \mathrm{sheep} \text { of nucleus } \\
\text { flock }\end{array}$ & $\begin{array}{l}\text { Sunny } \\
\text { Shady } \\
\text { SE }\end{array}$ & $\begin{array}{l}2.77 \\
2.68 \\
0.24 \text { ns }\end{array}$ & $\begin{array}{c}2.55 \\
\ddot{0} \\
0.20^{*}\end{array}$ & $\begin{array}{l}3.88 \\
0.32^{*}\end{array}$ \\
\hline $\begin{array}{l}\text { Net fleece gain as } \mathrm{kg} / \mathrm{ha} \text { (mean } \mathrm{S} / \mathrm{R} \text { until shearing } \\
\times \text { fleece growth of nucleus flock) }\end{array}$ & $\begin{array}{l}\text { Sunny } \\
\text { Shady }\end{array}$ & $\begin{array}{l}18.3 \\
34.3\end{array}$ & $\begin{array}{l}33.8 \\
33.2\end{array}$ & $\begin{array}{l}34.6 \\
36.2\end{array}$ \\
\hline
\end{tabular}


However, in the spring period to the end of November, similar or higher numbers of stock/ha were carried on the shady face compared to the sunny face and in two out of three years, these stock on the shady aspect also put on more weight. The details follow:

In year 1, the spring stocking rates were 6.1 /ha sunny, 8.5/ ha shady and weight gains/sheep were $15.5 \mathrm{~kg}$ sunny and $17.1 \mathrm{~kg}$ shady.

In year 2, stocking rates were 9.5/ha sunny and 12.9 /ha shady and weight gains/sheep were $13.3 \mathrm{~kg}$ sunny, $11.7 \mathrm{~kg}$ shady.

In year 3, stocking rates were 12.2 / ha for sunny and shady and weight gains/sheep were $7.7 \mathrm{~kg}$ sunny and $9.0 \mathrm{~kg}$ shady. Growth per sheep was significantly better on the sunny than the shady aspect in the first year (Table 4) when the sunny aspect carried less stock. But growth per sheep was better on the shady aspect in year 3 when mean seasonal stocking rates were comparable between aspects.

Sheep performance per hectare was better on the shady aspect in the first year when more stock were carried, but in the second and third years it was similar (Table 4).

Individual fleece weights were significantly better from the nucleus flock on the shady aspect in the second and third years (Table 4). Studies of wool growth from patch samples in the second year showed that this extra wool grew in January and February when sheep on the shady face were gaining weight and those on the sunny face were losing weight.

\section{DISCUSSION}

The bimodal pasture growth pattern differs from that on hill pastures at Whatawhata (Gillirigham, 1973), Te Kuiti (J. A. Baars, reported by Yeoman, 1973) and other flatland pastures (Radcliffe and Lynch, 1974). The causal factors for this pattern are being studied: the summer depression is probably related to winds and warm temperatures promoting evapotranspiration and creating high soil moisture tensions which restrict water and nutrient uptake by the pasture. Over the three years of measurement pasture on the shady aspect produced $14 \%$ more dry matter than that on the sunny aspect, partly because of the better soil moisture conditions and the higher fertility of these soils. 
The seasonal trends in digestibility of available pasture must be cautiously related to sheep growth because sheep selectively graze plants or parts of plants with higher digestibility. This selection may have been very important in summer and autumn, when the proportion of dead plant material increased substantially. Despite new autumn growth the digestibility of the total feed on offer rose to only 55 to $60 \%$. During this time sheep were probably selecting green growth of high digestibility. In spring higher levels of digestibility were accompanied by much lower levels of dead material. The later spring peak in digestibility on the shady compared with the sunny aspect may have been caused by lower soil temperatures and lower light intensities. The dramatic fall in digestibility on both aspects from December to mid-January was associated with maturity of browntop and a higher net accumulation of dead material relative to new growth.

Hoggets grew well on both aspects and reached a mating liveweight of 50 to $55 \mathrm{~kg}$ in early April which was better than average for this'class of hill country. The net liveweight gain/ha over the season disguises fluctuations within the season, such as the better spring growth of hoggets on the shady aspect in two years. Although net liveweight gain/ha was similar for the second and third years and mean seasonal stocking rates were similar, in fact there were compensating differences producing this effect caused by the interaction of stocking rate manipulation with hogget growth. In the third year net liveweight gain/ha up to shearing was slightly higher than in the second year but in this third year there was a net loss in production/ha post shearing.

Annual net sheep productivity/ha may not necessarily reflect total pasture DM production. Much depends on when the pasture grows and if stock can consume enough digestible feed. In the third year when pasture production was high, delayed spring growth and a colder frosty autumn may have restricted net liveweight gains/ha.

In summary:

(1) The seasonal pattern of pasture growth was similar on both aspects.

(2) The shady aspect produced as much and sometimes more dry matter from October to June than the sunny aspect.

(3) If feed availability was maintained at similar levels on sunny and shady aspects, then hoggets confined to the shady aspect grew as well as if not slightly better than those confined to the sunny aspect. 
(4) Hoggets on the shady aspect grew more wool over summer.

(5) The digestibility of the pasture on offer to stock on both aspects was very high in spring-early summer and thereafter followed the same seasonal trends.

The productivity of other hillsides and other classes of stock surely deserves study by grassland workers, as an aid in realizing the potential of New Zealand hill country.

\section{ACKNOWLEDGEMENTS}

We are grateful to many people at Lincoln College and especially at the Computer Centre, and to the Director and his staff at Tussock Grassland and Mountain Lands Institute for their willing assistance; and to K. M. Wells for his co-operation and use of land and stock. Biometrics Section, Ministry of Agriculture and Fisheries, assisted with data anaiyses.

\section{REFERFNCES}

Coop, I. E.: Darling, M.; Anderson. C. M., 1953. N.Z. // Sci. Technol. $34 A: \quad 507-20$

Gillingham, A. G. 1973. Proc. N.z. Grassld Ass.. 35: 77.85

Radcliffe. I. E.. 1971. Proc. N.Z. Grassld Ass.. 33: 91-104.

Radcliffe, J. E.; Lynch, P. B., 1974. Proc, 12th int. Grassld Congr., 1: 501 14.

Suckling, F. E. T., 1975. N.z. $/ /$ exp. Agric., 3: 351-436.

Tilley, J. M. A.; Terry, R. A., 1963. J. Br. Grassld Soc., 28: 101-I1.

White, J. G. H.: Meijer, G.; Langer, R. H. M., 1972. Proc. N.Z. Grassld Ass., 34: $139-46$.

Yeoman, P. G., 1973: Proc. N.Z. Grassld Ass.. 35: 44-51. 